\title{
The impact of the NFI Directive on the scope and quality of financial institutions' CSR reporting - the case of the Polish banking sector
}

\author{
JUSTYNA BERNIAK-WOŹNY \\ College of Management, \\ University of Information Technology and Management, 2 Sucharskiego St., Rzeszów, \\ POLAND \\ MAGDALENA WÓJCIK-JURKIEWICZ \\ Department of Accounting, College of Management Sciences and Quality, \\ Cracow University of Economics, 27 Rakowicka St., Cracow, \\ POLAND
}

\begin{abstract}
Until recently, CSR reporting in most EU countries was voluntary and not regulated by the State. However, many, especially large companies, have disclosed additional non-financial information on a voluntary basis in various ways. The situation changed with the entry into force of the EU Directive on disclosure of nonfinancial and diversity information, which required over 6,000 EU companies to report non-financial information. The aim of the article is to examine how the implementation of Directive 2014/95 / EU influenced the scope and quality of CSR reporting practices of financial institutions on the example of the Polish banking sector. The analysis in this study covered the content of non-financial information of the largest Polish banks listed on WIG Banki, a sub-index of the Warsaw Stock Exchange. The findings indicate that the banking sector reporting

practices, although significantly improved, are still at an early stage. To the best of the authors' knowledge, the research results are the first to present an in-depth analysis of the impact of the NFI Directive on the CSR

reports of financial institutions and their reviews. The findings of this study adds to our current knowledge and provides an overview of banking sector reporting practices, showing strengths and weaknesses in this area. The characteristics of banking sector practices presented in this document can help other financial institutions with CSR reporting and encourage them to adhere to recognized standards.
\end{abstract}

Keywords: CSR reporting, Directive 2014/95/EU, non-financial disclosure, banking sector, NFI, content analysis

Received: November 20, 2020. Revised: April 16, 2021. Accepted: April 25, 2021. Published: May 4, 2021.

\section{Introduction}

From the financial year, 2017, through the Directive 2014/95/EU [1], the EU requires almost 6,000 large public-interest companies to disclose non-financial information on environmental, social, employee-related matters, show respect for human rights, be anti-corruption, and fight bribery issues. One of the biggest groups covered by this new regulation is the financial sector companies, including banks. The financial crisis of 2008, and the failure of commercial banks, whose results impacted on the real economy, focused stakeholders' attention on the financial industry [2-5]. The crisis also drew attention to the necessity of CSR in this sector, as a response to the increasing need for trust, as well as accountability and transparency that lead to it [6]. The aim of the article is to examine how the implementation of Directive 2014/95 / EU influenced the scope and quality of CSR reporting practices of financial institutions on the example of the Polish banking sector.

The paper is structured as follows: first, a literature review will provide an overview of the CSR reporting, in general, and in financial institutions' reporting, including the banking sector, specifically. The second part introduces the methodology employed in this research and the justification of the sample. The research results are presented next, in the Results and Discussions sections, and the scope and quality of the reporting practices within six categories, namely employees, investors and shareholders, customers, business partners, community and environment, are analysed and interpreted. In the Conclusions section, the authors summarize the findings, identify the limitations of the research, and share ideas for future research.

This paper contributes to the international management literature, specifically to the existing 
research of CSR reporting. The focus of this research is, not only the scope of the CSR reporting, but also, by distinguishing between different types of qualitative and quantitative disclosures, the research provides an enhanced insight into the quality of reporting practices [7]. The results of the study will allow to determine the impact of changing the nature of CSR reports from non-obligatory to obligatory on the scope and quality of reporting, and will define trends in banking sector reporting, which in the future may become the basis for developing standards, frameworks and guidance in this area.

\section{Problem Formulation}

Corporate Social Responsibility (CSR) Reporting

The Corporates Social Responsibility as a concept has its origins in 1953, when Bowen published his book 'Social Responsibility of the Businessman' but the issue is much older and can be found in the business activities in the late 1800's, when Cadbury encouraged its employees to drink chocolate, rather than unsafe water or alcohol, as they believed it was healthier for them [8]. The CSR concept relates closely to corporate citizenship [9-10], corporate social responsiveness [11-12], and corporate social performance [13-15]. Common to these concepts is the idea that organisations should not only be concerned about making a profit, but also engaged in "actions that appear to further some social good, beyond the interests of the firm and things required by the law" [16] (p.1).

The history of CSR reporting is much shorter, as the first CSR reports are dated in the 1970s and were published in the United States and Western Europe [17-18]. However, CSR reporting gained importance in the late 1980s, and since then, are more and more popular and currently, are being applied by companies in high rates globally [19]. According to the KPMG Survey of Corporate Responsibility Reporting 2017, almost all (93\%) of the world's largest 250 companies and $75 \%$ of the 4,500 companies from 45 countries surveyed by KPMG [20] are reporting on CSR, either in stand-alone reports, or in annual management reports.

CSR reporting (named also 'sustainability reports', 'social reports', 'corporate social responsibility reports', 'Environmental, Social and Governance (ESG) reports' and 'non-financial reports') can be characterised as a systematic tool to collect and present CSR initiatives to stakeholders, such as employees, shareholders, customers, local communities, NGOs, investors or financial analysts. Its aim is to provide transparency and accountability in the issues that traditional financial reporting is not dealing with [21-22].

The discussion about CSR reporting, includes the obligatory vs the voluntary aspect. Even though a business report on CSR, is produced, mostly because of the stakeholders' pressure, and not because of the legal requirements, there are more and more countries and international bodies that make CSR disclosure obligatory (for example, India, China, and South Africa). However, making the CSR reporting mandatory, does not bring full transparency and comparability, as the approach to CSR reporting is country/region and culture dependant, and is strongly tied to industry/sector specifics. The aim of CSR reporting is to make a platform between the different levels of management, shareholders, and investors, and other stakeholders, and support the win-win strategy that lead to the sustainable development, not only of the business, but of whole industries. Meanwhile, as highlighted by the Chartered Institute of Management Accountants, "there is no comparability of non-financial information, so anyone trying to understand performance needs to learn a new language for every report they read" [23] (p.13). Reporting organisations can adapt a wide palette of standards, frameworks, and guidance (GRI, ESG, ISO 26000, OECD, and many others). This diversity becomes problematic in the case of communication with shareholders, investors, and business partners, who need standardised and transparent information. For business effective reporting, in accordance with the growing number of standards and legal requirements, it is both inefficient, ineffective, and resource consuming.

\section{The EU Directive on the disclosure of non- financial and diversity information}

The introduction of the EU's Directive on the disclosure of non-financial and diversity information [1] is considered as the changing point in NFI disclosure in the European Union, including CSR reporting. The $28 \mathrm{EU}$ Member States have had to transpose the Directive into their own national legislations, and as a result, about 6,000 large publicinterest companies are now expected to comply with the new disclosure requirements of the locally transposed laws from 2018, meaning they will add a non-financial declaration to their annual management report, or publish a separate report.

According to the Directive, the required nonfinancial information (NFI) is "information to the extent necessary for an understanding of 
the undertaking's development, performance, position, and impact of its activity, relating to, as a minimum, environmental, social, and employee matters, respect for human rights, anticorruption and bribery matters, including: (a) a brief description of the undertaking's business model; (b) a description of the policies pursued by the undertaking in relation to those matters, including due diligence processes implemented; (c) the outcomes of those policies; (d) the principal risks related to those matters, linked to the undertaking's operations including, where relevant and proportionate, its business relationships, products, or services, which are likely to cause adverse impacts in those areas, and how the undertaking manages those risks; and (e) non-financial key performance indicators relevant to the particular business".

The Directive is a big step towards eliminating the main barriers of using non-financial information in investment decision-making, which are defined as a lack of appropriate quantitative environmental, social, and governance information (55\%), lack of comparability over time (50\%), and questionable data quality (45\%) [24]. Due to the above limitations, investors consider the use of non-financial information as time consuming and costly. Having said that, it must be highlighted that the Directive allows Member States to impose state specific requirements on companies regarding the reporting framework, disclosure format, and reporting of content, which makes comparing NFI within and across sectors, still challenging.

On December the 15th, 2016, the EU's NonFinancial Directive was also transposed into Polish legislation by the Act of amending the Accounting Act 61. The new regulations would cover large Public Interest Entities (PIEs), having headquarters in Poland, including listed companies, insurance undertakings, investment undertakings, pension funds, national payment institutions, electronic money institutions and banks. There are estimated to be 300 of such entities in Poland. The basic criterion that verifies whether a listed company is obliged to report non-financial information, is the number of employees - above 500. Additionally, one of two financial criteria must be fulfilled - revenues exceeding PLN 170 million or total assets exceeding PLN 85 million.

\section{CSR reporting of the financial institutions}

The financial institutions affect individuals and businesses, both nationally and globally. The sector services are a backbone of the real economy, as they encompass a significant range of activities with public and private money. Thus, there is more and more pressure on financial institutions to be more sustainable and transparent in terms of non-financial areas. This is not only political pressure, but also financial and market pressure. Let us mention, for example, the Principles of Responsible Investment (PRI) initiative [25], signed by 1,800 members (investors and banks) obligated to fulfil the Six Principles.

According to the report 'Tomorrow's Investment Rules 2.0' prepared by EY, $70 \%$ of global and $80 \%$ of European investors, consider integrated reports (covering both - financial and non-financial information) to be essential or important in making investment decisions. It is worth mentioning that, in 2015, the percentage of investors who considered integrated reports to be a key source for making investment decisions, increased by $10 \%$ when compared to 2014. The number of investors, who think that ESG factors are important, regardless of the sector, has risen by $50 \%$, and now reaches over $61 \%$ [26].

A decade ago, when the financial crisis of 2008 had started, both academics and practitioners agreed that financial institutions were the ones to be blamed, due to their irresponsibility [27]. Currently, the financial sector is often viewed as a leader in the CSR field [28]. In its survey of global trends in CR reporting, KPMG reports that among the 100 companies it surveyed, $17 \%$ were classified as financial services sector companies using the International Classification Benchmark System. However, there is still a commonly held public perception that reporting by the Financial Sector is inadequate. One of the reasons may be the fact that the financial services are diverse and complex, encompassing several industries or sub-sectors, such as:

- Banking: retail savings, commercial investments, development finance (national and multi-national), Central Banks,

- Investments: Institutional investments Longterm collective (e.g., pension funds), Retail investments, Stock or securities exchanges, Asset Management,

- Insurance: Long and short-term.

and each industry should be investigated and assessed separately.

According to Scholtens [29], CSR is an increasingly important issue in the international banking industry. Banks implemented the CSR concept relatively late, first focusing on environmental, then social issues [30]. Thus, an empirical investigation [31] shows many late adopters of CSR reporting in the banking sector, compared to the other sectors. The traditional 
approach of banks to CSR is often characterised as reactive and defensive. However, several international banks have recently adopted innovative, proactive strategies, and developed new products, such as ethical funds, or loans specifically designed for environmental businesses to capture new market opportunities associated with sustainability.

Scholtens [29] states that socially responsible banking is becoming a very popular concept. According to him, financial institutions have realised that CSR may support investments decision-making using the CSR performance factor. According to the KPMG Survey of Corporate Responsibility Reporting, 2015, findings on the Banking sector, show that the banks have the highest rate of CSR reporting. All the world's largest banks, and over four fifths of smaller N100 banks, report on corporate responsibility. This suggests that CSR reporting is well-established as a standard business practice in the banking sector. Banks are more likely to present CSR information in their annual financial report than companies in any other sector. Almost all (93 percent) of the largest banks do so, which is almost 30 percentage points above the global average (65 percent).

\section{Materials and methods}

The aim of the paper is to investigate how the implementation of the Directive 2014/95/EU [1], impacted upon the scope and the quality of Polish banks' CSR reporting practices. The nature of the study is descriptive and based solely on information from secondary data sources of banking companies.

The banking sector in Poland plays a dominant role in the financial system, accounting for around $70 \%$ of financial sector assets. Poland is home to several state-owned banks, though most banks in the country are privately owned, taking around $80 \%$ of the market. The state owns several banks, but the sector is largely (around 80\%) privately owned. According to the Polish Financial Supervision Authority (KNF), in February 2020 there were 30 locally registered commercial banks in the country a decrease from 50 in the last five years, which proves the intensive consolidation of the sector. There are many cooperative banks (over 500), but in total they have a relatively small market share [32]. Thus the research will focus on the biggest ones listed on the WIG banks sub-index of the Warsaw Stock Exchange that covers both state-owned and privately owned banks and obliged to report non-financial information.

There is a limited, but interesting set of research on CSR in the Polish banking sector [33-36]. The study that can serve as the reference is the one conducted by Krasodomska [37], who analysed the CSR reporting practices of 12 banks operating in Poland in the years, 2005-2011. The research revealed that banks tend to include CSR disclosures in management's annual reports. They present CSR information in a diverse manner, focusing mainly on community involvement. The quality of CSR disclosures in 2011 was higher when compared with 2005 , so the trend was positive. The current research will develop our knowledge in this field.

The sample banking companies include the 10 biggest Polish banks listed on the WIG Banks, subindex of the Warsaw Stock Exchange, namely: ALIOR, BOŚ, SANTANDER (previously BZWBK), CITI HANDLOWY (previously HANDLOWY), IDEABANK, INGBSK, MBANK, MILLENIUM, PEKAO, PKOBP. The index consists of 13 listed banks, but three banks must have been excluded (Banco Santander SA, BGŻ BNP Paribas SA, and UniCredit SA) as they are international financial groups, which do not publish annual and CSR reports for Polish markets. In the case of Banco Santander $\mathrm{SA}$, the group is the majority owner of Bank Zachodni WBK SA, one of the 10 banks included in the sample. The analysis was conducted for the two reporting years, - 2016 (published in 2017) and 2019 (published in 2020) - before and after the Directive 2014/95/EU's transposition into Polish law. The data gathering, and analysis was conducted in two periods - in December 2017, and in December 2020, to identify and assess the reporting scope and quality before and after implementation of the Directive.

It has been argued that annual reports are the single most important source of information on corporate activities [38]. However, the global pressures motivated the push toward stand-alone CSR reporting [39], and this trend was also followed by the social reporting researchers, who focused their analysis on stand-alone CSR reports [40-41]. According to KPMG [20], we can now witness a strong trend for large companies to include CSR information in their annual financial reports again78 percent of the world's top companies (G250) did so in 2017, compared to 44 percent in 2011. That is why research, based only on annual reports, or standalone reports, might not produce particularly relevant results. Obviously, there is a much wider array of CSR sources as a sampling unit, including e.g., webpages, brochures, and advertisements, and other ad hoc documents published each year. Nevertheless, as Unerman [40] points out, "a limit must be set to the range of documents included in any research study... (due to the risk of) a researcher being overwhelmed by the number of documents... 
(and of not being) possible to ensure the completeness of data" (p. 671). According to Vourvachis [41], researchers who use the content analysis method in CSR reporting research as a sampling unit choose annual reports (76\%), standalone reports $(26 \%)$, and the internet (14\%). It, therefore, seems justifiable for this study to employ annual reports, and CSR stand-alone reports, and banks' websites as the sampling unit, as these should contain the bulk of the disclosed CSR information. Tables 1 and 2 present the detailed sources of information available in the case of all sample banks, in the years 2016 and 2019.

Table 1. CSR sampling units for 2016 reporting year (published in 2017)

\begin{tabular}{|c|c|c|c|c|c|c|c|c|c|c|}
\hline 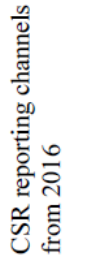 & $\frac{\stackrel{0}{0}}{\stackrel{u}{\gtrless}}$ & O̊ & 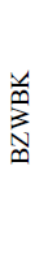 & 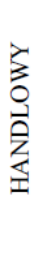 & 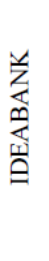 & 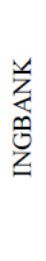 & $\begin{array}{l}\frac{y}{k} \\
\frac{m}{\Sigma}\end{array}$ & 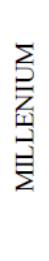 & $\frac{0}{4}$ & $\begin{array}{l}\frac{0}{m} \\
0 \\
\frac{1}{2}\end{array}$ \\
\hline $\begin{array}{l}\text { Annual } \\
\text { report }\end{array}$ & & & & & & $\mathrm{x}$ & $x$ & $\mathrm{x}$ & $\mathrm{x}$ & $\mathrm{x}$ \\
\hline $\begin{array}{l}\text { Stand- } \\
\text { alone } \\
\text { report }\end{array}$ & & $\mathrm{x}$ & $\mathrm{x}$ & & $x$ & & & & & \\
\hline $\begin{array}{l}\text { Bank } \\
\text { website }\end{array}$ & $\mathrm{x}$ & $\mathrm{x}$ & $\mathrm{x}$ & $\mathrm{x}$ & $\mathrm{x}$ & $\mathrm{x}$ & $\mathrm{x}$ & $\mathrm{x}$ & $\mathrm{x}$ & $\mathrm{x}$ \\
\hline
\end{tabular}

Source: Authors' own study

Table 2. CSR sampling units for 2019 reporting year (published in 2020)

\begin{tabular}{|c|c|c|c|c|c|c|c|c|c|c|}
\hline 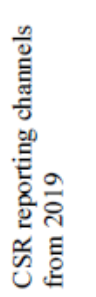 & $\frac{\frac{\alpha}{0}}{\frac{3}{2}}$ & oి & 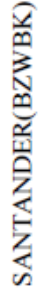 & 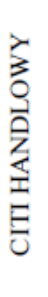 & 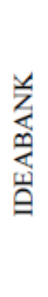 & $\begin{array}{l}\text { 乥 } \\
\text { 怘 } \\
\text { 号 } \\
\text { Z }\end{array}$ & 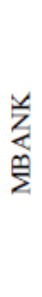 & 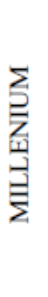 & 啇 & $\begin{array}{l}\text { 商 } \\
\frac{0}{2} \\
\frac{1}{a}\end{array}$ \\
\hline $\begin{array}{l}\text { Annual } \\
\text { report }\end{array}$ & $x$ & $x$ & $x$ & $x$ & $x$ & $x$ & $\mathrm{x}$ & $x$ & $x$ & $\mathrm{x}$ \\
\hline $\begin{array}{l}\text { Stand- } \\
\text { alone } \\
\text { report }\end{array}$ & & $x$ & & & & & & $x$ & $x$ & \\
\hline $\begin{array}{l}\text { Bank } \\
\text { website }\end{array}$ & $x$ & $x$ & $x$ & $x$ & $x$ & $x$ & $x$ & $x$ & $x$ & $x$ \\
\hline
\end{tabular}

Source: Authors' own study

To investigate the scope and quality of CSR reports, a qualitative descriptive research design was selected that provides a comprehensive understanding of the topic under study and therefore is consistent with the purpose of this study. There are many approaches to how qualitative research is designed and implemented, such as case study, grounded theory, ethnographic, and content analysis, among others. In this study, the content analysis will be performed. The content analysis is assumed to be "the research method that is most commonly used to assess organisations' social and environmental disclosures" [41] (p. 237). One of the key advantages is that the content analysis method allows one to analyse data qualitatively, and at the same time, quantify the data [42].

Content analysis is commonly understood as a general term covering several different text analysis strategies [43]. Following Krippendorff [44] (p. 24), we can define content analysis as "a research technique for making replicable and valid inferences from texts (or other meaningful matter) to the contexts of their use". Content analysis is also defined as a systematic approach to coding and categorizing, used to explore large amounts of text, to define trends and patterns of words (or problems) used, their frequency, relationships, and communication structures and discourses [46-47].

The main purpose of content analysis is to describe the phenomenon in a conceptual form. Therefore, a well-defined data analysis process is necessary, and should cover the following stages [48] (p. 110):

- Preparation: immersion in data and getting a sense of the whole, choosing the unit of analysis, deciding on the analysis of explicit or hidden content manifest.

- Organizing: open coding and creating categories, grouping codes under higherorder headings, formulating a general description of the research topic by generating categories and subcategories.

- Reporting: reporting the analysis process and results using models, conceptual frameworks, concept maps or categories, and a story line.

In this study the data analysis process was performed by two researchers. At the Preparation stage, all available annual reports, CSR reports, and webpages of the 10 sample banks, were collected. Regarding annual reports, only the reports for 2016 and 2019 were collected. The researchers then immersed themselves in the collected data and defined the basic categories of analysis. The main categories of CSR defined by Gray et al. [49] were used and expanded and the following 6 categories were obtained: employees, customers, business partners, investors and shareholders, community, and the environment.

The content analysis method offers researchers a choice between 'index' approach and 'volumetric' 
approach. Volumetric approach checks the overall volume of disclosure, most often by counting words, sentences, or the aspect ratio of an A4 page. Index approach, on the other hand, checks the presence or absence of specific information [50]. As the aim of the study is to examine the scope and quality of NFI reporting, it is necessary to choose the index approach because it is not the number of pages or words that we are interested in, but the presence or absence of the ex-ante specified issues and the quality of disclosure on these issues in the report. This decision is supported by other researchers, who have used the disclosure index to assess the quality of sustainability reporting [51-52].

In index approach, a simple binary coding scheme is often used, in which a score of 1 or 0 is respectively assigned with or without the element. Other coding schemes include ordinal measures to allow the quality of a particular disclosure to be assessed [46] as used by Wiseman [7], who used a four-level index. This index was adapted and used in many studies [5355]. Although we can find several other scientistdeveloped disclosure indexes in field studies [56-58], this study adjusts the four-level Wiseman index [7]:

- three (3) points are awarded if an issue is disclosed and described in monetary or quantitative terms.

- two (2) points are awarded if an issue is disclosed but on a non-quantitative basis.

- one (1) point is awarded for an issue generally disclosed, and

- zero (0) is awarded if an issue is not disclosed.

At the Organizing stage, the researchers identified an initial list of issues under each of the 6 categories. Researchers then looked at the disclosures in the form of reports and web pages (by reading them several times). The issues defined at the beginning were then verified based on the content of the disclosures. Ultimately, 36 issues grouped into 6 main categories were used to examine the scope and quality of CSR reporting by selected Polish banks.

After conducting individual analyses, the researchers discussed all discrepancies, and the agreed assessments are presented in the next section of the paper (Reporting stage).

\section{Results}

As mentioned above, six basic categories of CSR were used in the data analysis preparation stage, namely: employees, investors and shareholders, customers, business partners, community and the environment. The presentation of the results will be in line with these categories.

\section{Employee issues reporting by Polish banks}

In the case of employee issues disclosed in 2017 for 2016 by the banks selected for analysis, the scope is quite wide, but the quality of disclosures should be assessed poorly (Table 3). Most of the analyzed reports contained only general information. Job satisfaction and communication (1.4) as well as wages and working conditions (1.3) were rated the highest. The lowest scores were given to work-life balance and dealing with corruption and unethical behavior ( 0.8 and 0.9 , respectively). From the point of view of the reporting organizations, average scores ranged from 0.67 to 2.0. Most of the sample organizations scored above 1.0.

Employee issues are much better both in terms of scope and quality in the reports for 2019 (Table 4). Learning and development and diversity management and equal opportunities were rated the highest - both issues received score 2.6. The lowest results are again achieved by work-life balance (1.4) and employee engagement (1.8). From the point of view of reporting organizations, average results ranged from 1.56 to 2.89 . This time, only one analyzed bank was rated below 2.0 .

Table 3. Employee issues reporting by Polish banks 2016 reporting year (published in 2017)

\begin{tabular}{|c|c|c|c|c|c|c|c|c|c|c|c|}
\hline$\stackrel{n}{\underline{y}}$ & $\frac{\frac{2}{0}}{2}$ & $\varrho_{0}^{\infty}$ & $\frac{1}{N}$ & 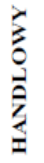 & 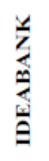 & 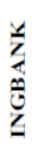 & $\begin{array}{l}\frac{1}{2} \\
\frac{1}{2}\end{array}$ & 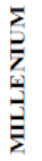 & $\frac{0}{2}$ & $\begin{array}{l}\frac{\hat{\theta}}{0} \\
\frac{1}{2}\end{array}$ & $\begin{array}{l}\frac{1}{0} \\
\frac{\pi}{x} \\
\frac{x}{4} \\
\frac{1}{4}\end{array}$ \\
\hline $\begin{array}{l}\text { Wages and } \\
\text { working } \\
\text { conditions }\end{array}$ & 1 & 1 & 2 & 2 & 2 & 1 & 1 & 1 & 1 & 1 & 1,30 \\
\hline $\begin{array}{l}\text { Occupational } \\
\text { health and safety }\end{array}$ & 1 & 1 & 2 & 1 & 2 & 1 & 1 & 1 & 1 & 1 & 1,20 \\
\hline $\begin{array}{l}\text { Learning and } \\
\text { development }\end{array}$ & 1 & 1 & 2 & 1 & 2 & 1 & 1 & 1 & 1 & 1 & 1,20 \\
\hline $\begin{array}{l}\text { Job satisfaction } \\
\text { and } \\
\text { communication }\end{array}$ & 1 & 1 & 2 & 2 & 2 & 2 & 1 & 1 & 1 & 1 & 1,40 \\
\hline $\begin{array}{l}\text { Employee } \\
\text { engagement }\end{array}$ & 1 & 1 & 2 & 1 & 1 & 1 & 1 & 1 & 1 & 1 & 1,10 \\
\hline $\begin{array}{l}\text { Diversity } \\
\text { management and } \\
\text { equal } \\
\text { opportunities }\end{array}$ & 0 & 1 & 2 & 2 & 2 & 1 & 2 & 1 & 0 & 0 & 1,10 \\
\hline $\begin{array}{l}\text { Work Life } \\
\text { Balance }\end{array}$ & 0 & 1 & 2 & 1 & 1 & 1 & 1 & 1 & 0 & 0 & 0,80 \\
\hline $\begin{array}{l}\text { Employer } \\
\text { supported } \\
\text { volunteering }\end{array}$ & 1 & 1 & 2 & 1 & 1 & 1 & 1 & 1 & 1 & 1 & 1,10 \\
\hline $\begin{array}{l}\text { Dealing with } \\
\text { corruption and } \\
\text { unethical } \\
\text { behaviour }\end{array}$ & 0 & 1 & 2 & 1 & 1 & 1 & 1 & 1 & 1 & 0 & 0,90 \\
\hline $\begin{array}{l}\frac{5}{0} \\
\frac{3}{2} \\
\frac{2}{4}\end{array}$ & $\underline{6}$ & $\stackrel{0}{-}$ & $\stackrel{\text { : }}{i}$ & 2 & $\stackrel{i_{2}}{2}$ & 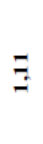 & $\Xi$ & $\stackrel{8}{-}$ & $\stackrel{\infty}{\stackrel{\infty}{0}}$ & $\stackrel{t}{6}$ & $\cong$ \\
\hline
\end{tabular}

Source: Authors' elaboration 
Table 4. Employee issues reporting by Polish banks - 2019 reporting year (published in 2020)

\begin{tabular}{|c|c|c|c|c|c|c|c|c|c|c|c|}
\hline 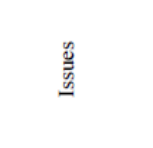 & $\frac{\frac{\alpha}{0}}{\frac{1}{2}}$ & $\overbrace{\infty}^{\infty}$ & $\sum_{\substack{c \\
\vdots}}$ & Eี & 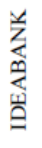 & 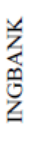 & 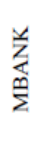 & 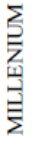 & $\underset{\substack{0 \\
\frac{1}{2}}}{2}$ & $\begin{array}{l}\text { ⿳亠丷厂巾 } \\
0 \\
\frac{1}{2}\end{array}$ & 过 \\
\hline $\begin{array}{l}\text { Wages and } \\
\text { working } \\
\text { conditions }\end{array}$ & 3 & 3 & 3 & 2 & 2 & 3 & 3 & 3 & 2 & 3 & 2,5 \\
\hline $\begin{array}{l}\text { Occupational } \\
\text { health and } \\
\text { safety }\end{array}$ & 2 & 3 & 2 & 2 & 1 & 2 & 3 & 3 & 3 & 3 & 2,4 \\
\hline $\begin{array}{l}\text { Learning and } \\
\text { development }\end{array}$ & 3 & 3 & 3 & 2 & 1 & 3 & 2 & 3 & 3 & 3 & 2,6 \\
\hline $\begin{array}{l}\text { Job satisfaction } \\
\text { and } \\
\text { communication }\end{array}$ & 2 & 1 & 3 & 2 & 1 & 2 & 2 & 3 & 2 & 2 & 2,0 \\
\hline $\begin{array}{l}\text { Employee } \\
\text { engagement }\end{array}$ & 1 & 1 & 2 & 2 & 1 & 2 & 2 & 2 & 3 & 2 & 1,8 \\
\hline $\begin{array}{l}\text { Diversity } \\
\text { management } \\
\text { and equal } \\
\text { opportunities }\end{array}$ & 3 & 1 & 3 & 2 & 3 & 3 & 3 & 3 & 3 & 2 & 2,6 \\
\hline $\begin{array}{l}\text { Work Life } \\
\text { Balance }\end{array}$ & 1 & 1 & 2 & 1 & 1 & 2 & 1 & 3 & 1 & 1 & 1,4 \\
\hline $\begin{array}{l}\text { Employer } \\
\text { supported } \\
\text { volunteering }\end{array}$ & 2 & 3 & 3 & 3 & 1 & 3 & 1 & 3 & 2 & 1 & 2,2 \\
\hline $\begin{array}{l}\text { Dealing with } \\
\text { corruption and } \\
\text { unethical } \\
\text { behaviour }\end{array}$ & 2 & 1 & 3 & 2 & 3 & 3 & 3 & 3 & 3 & 1 & 2,4 \\
\hline 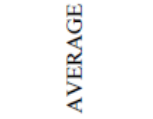 & $\overrightarrow{\vec{N}}$ & $\stackrel{\infty}{-}$ & $\stackrel{\bullet}{:}$ & $\stackrel{\text { i }}{\text { i }}$ & $\stackrel{0}{\dddot{n}}$ & $\begin{array}{l}\stackrel{0}{n} \\
\vec{n}\end{array}$ & तี & $\underset{\text { ¿े }}{\text { i }}$ & $\underset{i}{\text { 守 }}$ & i & तี \\
\hline
\end{tabular}

Source: Authors' elaboration

\section{Investors and shareholders issues reporting by Polish banks}

Investor and stakeholder issues disclosed in 2017 for 2016, by the sample banks should be assessed poorly in terms of both scope and quality (Table 5). The analyzed reports mainly included general disclosure or did not disclose the analysed issues at all. The highest scores were granted to the presence on sustainability indices (1.1) and disclosing information for investors (1.1). The lowest scores were achieved by the release of investor relations information and shareholder remuneration (both of 0.7). Looking at the results from the reporting organizations' point of view, the average scores ranged from 0.25 to 1.75 .

As for the disclosures presented in 2020, for the year 2019, by the sample banks, both the scope and quality received higher scores (Table 6). The analysed reports still covered mostly general disclosure, but there was no case of an absent discloser. The highest scores were again granted to the presence on sustainability indices (2.0) and disclosing information for investors (1.8). The slightly lower scores are reached by the release of investor relations information $(1,7)$ and shareholder remuneration $(1,5)$. All of the sample organisations were granted a score over 1.0.
Table 5. Investors and shareholders issues reporting by Polish banks - 2016 reporting year (published in 2017)

\begin{tabular}{|c|c|c|c|c|c|c|c|c|c|c|c|}
\hline 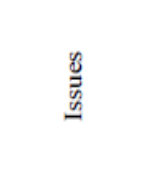 & $\frac{\frac{\pi}{0}}{\frac{1}{4}}$ & $\begin{array}{l}n \\
0 \\
0\end{array}$ & 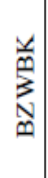 & 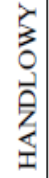 & 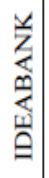 & 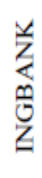 & 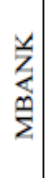 & 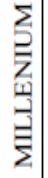 & $\begin{array}{l}0 \\
y \\
\frac{y}{2} \\
\frac{1}{2}\end{array}$ & $\begin{array}{l}0 \\
0 \\
0 \\
\frac{1}{2}\end{array}$ & $\frac{\frac{1}{0}}{\frac{\pi}{2}}$ \\
\hline $\begin{array}{l}\text { Disclosing } \\
\text { information for } \\
\text { investors }\end{array}$ & 1 & 1 & 1 & 1 & 1 & 1 & 1 & 1 & 1 & 1 & 1,00 \\
\hline $\begin{array}{l}\text { Release of } \\
\text { investor } \\
\text { relations } \\
\text { information } \\
\end{array}$ & 0 & 0 & 1 & 1 & 1 & 1 & 2 & 0 & 1 & 0 & 0,70 \\
\hline $\begin{array}{l}\text { Shareholder } \\
\text { remuneration }\end{array}$ & 1 & 0 & 0 & 1 & 1 & 2 & 2 & 0 & 0 & 0 & 0,70 \\
\hline $\begin{array}{l}\text { Presence on } \\
\text { sustainability } \\
\text { indices }\end{array}$ & 0 & 2 & 2 & 1 & 1 & 1 & 2 & 1 & 1 & 0 & 1,10 \\
\hline$\frac{5}{0}$ & $\stackrel{\vec{n}}{6}$ & $\stackrel{n}{?}$ & $\stackrel{0}{-}$ & $\stackrel{\mathscr{\Xi}}{-}$ & $\stackrel{8}{-}$ & $\stackrel{\text { İ }}{-}$ & $\stackrel{n}{2}$ & $\stackrel{7}{\circ}$ & $\begin{array}{l}n \\
6 \\
-\end{array}$ & : & $\begin{array}{l}\infty \\
\stackrel{\infty}{\infty} \\
\stackrel{0}{0}\end{array}$ \\
\hline
\end{tabular}

Source: Authors' elaboration

Table 6. Investors and shareholders issues reporting by Polish banks - 2019 reporting year (published in 2020)

\begin{tabular}{|c|c|c|c|c|c|c|c|c|c|c|c|}
\hline $\begin{array}{l}\underline{y} \\
\stackrel{y}{u} \\
\underline{u}\end{array}$ & $\frac{\frac{v}{0}}{2}$ & $b_{i}^{1}$ & 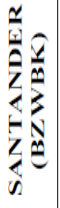 & 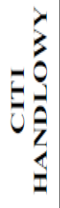 & $\begin{array}{l}\frac{y}{Z} \\
\frac{1}{3} \\
\vdots \\
\vdots\end{array}$ & 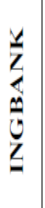 & $\begin{array}{l}\frac{y}{z} \\
z \\
\frac{0}{z}\end{array}$ & $\begin{array}{l}\bar{z} \\
\bar{z} \\
\bar{z} \\
\bar{z} \\
\bar{z} \\
\bar{z}\end{array}$ & $\begin{array}{l}0 \\
\frac{1}{2}\end{array}$ & $\begin{array}{l}\hat{M} \\
0 \\
\frac{1}{2}\end{array}$ & $\begin{array}{l}\frac{\pi}{2} \\
\frac{\pi}{2} \\
\frac{\alpha}{2} \\
2\end{array}$ \\
\hline $\begin{array}{l}\text { Disclosing } \\
\text { information for } \\
\text { investors }\end{array}$ & 1 & 1 & 3 & 2 & 2 & 2 & 2 & 2 & 2 & 1 & 1,80 \\
\hline $\begin{array}{l}\text { Release of investor } \\
\text { relations information }\end{array}$ & 1 & 1 & 3 & 2 & 2 & 2 & 2 & 2 & 1 & 1 & 1,70 \\
\hline $\begin{array}{l}\text { Shareholder' } \\
\text { remuneration }\end{array}$ & 1 & 1 & 3 & 1 & 1 & 2 & 2 & 1 & 1 & 2 & 1,50 \\
\hline $\begin{array}{l}\text { Presence on } \\
\text { sustainability indices }\end{array}$ & 2 & 2 & 2 & 1 & 1 & 2 & 2 & 3 & 3 & 2 & 2,00 \\
\hline 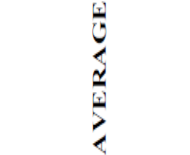 & $\begin{array}{l}\text { In } \\
=\end{array}$ & 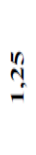 & $\begin{array}{l}\text { in } \\
\text { ? }\end{array}$ & $\stackrel{0}{n}$ & $\stackrel{8}{=}$ & $\overbrace{i}^{\circ}$ & 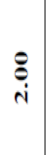 & 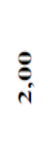 & $\begin{array}{l}n \\
= \\
=\end{array}$ & 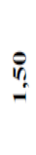 & $\begin{array}{l}10 \\
=\end{array}$ \\
\hline
\end{tabular}

Source: Authors' elaboration

\section{Customers' issues reporting by Polish banks}

When examining bank disclosures published in 2017 for 2016 regarding customer issues, it should be noted that the quality was very low and the scope of reporting was quite narrow (Table 7). Most of the analysed reports focused on quality of service communication $(1,3)$, and quality and 
efficiency of service, together with dialogue with customers and customer data safety (all 1,2). The industry's support of disadvantaged customers and compliance issues is very low (both 0,5 ), as well as the customer satisfaction and "closed loop" (0.7). From the point of view of the reporting organizations, the average results were rather low, ranging from 0.56 to 1.67 .

Table 7. Customers' issues reporting by Polish banks - 2016 reporting year (published in 2017)

\begin{tabular}{|c|c|c|c|c|c|c|c|c|c|c|c|}
\hline 总 & $\begin{array}{l}\frac{0}{0} \\
\frac{\partial}{<}\end{array}$ & $\begin{array}{l}n \\
0 \\
m\end{array}$ & 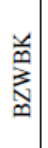 & 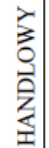 & 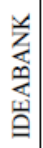 & 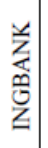 & 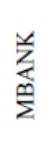 & 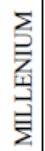 & 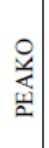 & $\begin{array}{l}\text { के } \\
\circ \\
\frac{2}{2}\end{array}$ & $\frac{\sqrt{3}}{\frac{2}{3}}$ \\
\hline $\begin{array}{l}\text { Dialogue with } \\
\text { customers }\end{array}$ & 1 & 1 & 2 & 1 & 2 & 1 & 2 & 1 & 0 & 1 & 1,20 \\
\hline $\begin{array}{l}\text { Customer } \\
\text { satisfaction and } \\
\text { "Closed loop" }\end{array}$ & 0 & 1 & 2 & 0 & 1 & 1 & 1 & 1 & 0 & 0 & 0,70 \\
\hline $\begin{array}{l}\text { Quality and } \\
\text { efficiency of } \\
\text { service }\end{array}$ & 0 & 2 & 2 & 2 & 2 & 1 & 1 & 1 & 1 & 0 & 1,20 \\
\hline $\begin{array}{l}\text { Quality of } \\
\text { service } \\
\text { communication }\end{array}$ & 1 & 2 & 2 & 1 & 1 & 1 & 2 & 1 & 1 & 1 & 1,30 \\
\hline $\begin{array}{l}\text { Complaint } \\
\text { handling } \\
\text { procedures }\end{array}$ & 1 & 1 & 1 & 1 & 1 & 1 & 1 & 1 & 1 & 1 & 1,00 \\
\hline $\begin{array}{l}\text { Customer data } \\
\text { safety }\end{array}$ & 1 & 1 & 2 & 1 & 1 & 1 & 2 & 1 & 1 & 1 & 1,20 \\
\hline $\begin{array}{l}\text { Multi- } \\
\text { channel strategy } \\
\text { and } \\
\text { accessibility / } \\
\text { Market presence }\end{array}$ & 1 & 0 & 2 & 1 & 1 & 1 & 1 & 1 & 1 & 1 & 1,00 \\
\hline Compliance & 1 & 1 & 0 & 1 & 0 & 1 & 0 & 0 & 1 & 0 & 0,50 \\
\hline $\begin{array}{l}\text { Disadvantaged } \\
\text { customers }\end{array}$ & 0 & 0 & 2 & 1 & 0 & 1 & 0 & 0 & 1 & 0 & 0,50 \\
\hline $\begin{array}{l}\frac{1}{0} \\
\frac{2}{2} \\
\frac{2}{2}\end{array}$ & : & $\stackrel{-}{-}$ & . & $\stackrel{\Xi}{=}$ & $\stackrel{\Xi}{-}$ & $\stackrel{0}{-}$ & $\Xi$ & $\stackrel{\infty}{\circ}$ & $\begin{array}{l}\infty \\
\stackrel{0}{=}\end{array}$ & ?:? & $\stackrel{\circ}{6}$ \\
\hline
\end{tabular}

Source: Authors' elaboration

When it comes to the sample bank's CSR reporting of customers' issues for the year 2019 it should be noted that the quality and scope of the reporting was much better (Table 8). Most of the analysed reports focused on the dialog with customers and customer data safety (both 2.0), and customers' satisfaction and "closed loop" together with quality and efficiency of service (both 1,9). Still, the industry's support of disadvantaged customers, compliance issues and complaint procedures are rather low (both 1,6), as well as the market presence and accessability $(1,5)$. From the sample banks' perspective the average scores were moderately good, ranging from 0,89 to 2,22 .
Table 8. Customers' issues reporting by Polish banks - 2019 reporting year (published in 2020)

\begin{tabular}{|c|c|c|c|c|c|c|c|c|c|c|c|}
\hline $\begin{array}{l}n \\
\stackrel{0}{0} \\
0 \\
\stackrel{0}{n}\end{array}$ & $\begin{array}{l}\frac{x}{0} \\
\frac{1}{2}\end{array}$ & $0_{0}^{\infty}$ & 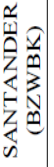 & 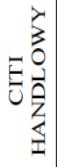 & 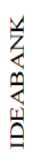 & 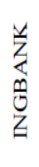 & $\begin{array}{l}\frac{1}{z} \\
\sum \\
\sum \\
\sum\end{array}$ & 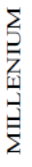 & $\begin{array}{l}0 \\
\frac{1}{2} \\
\frac{10}{2}\end{array}$ & $\begin{array}{l}\frac{1}{0} \\
0 \\
\frac{1}{2}\end{array}$ & $\begin{array}{l}\frac{11}{0} \\
0 \\
\frac{1}{2} \\
\frac{1}{12} \\
\frac{3}{4}\end{array}$ \\
\hline $\begin{array}{l}\text { Dialogue with } \\
\text { customers }\end{array}$ & 1 & 1 & 2 & 2 & 2 & 3 & 2 & 2 & 3 & 2 & 2,00 \\
\hline $\begin{array}{l}\text { Customer satisfaction } \\
\text { and "Closed loop" }\end{array}$ & 1 & 1 & 2 & 2 & 3 & 3 & 2 & 2 & 1 & 2 & 1,90 \\
\hline $\begin{array}{l}\text { Quality and efficiency } \\
\text { of service }\end{array}$ & 1 & 2 & 2 & 2 & 2 & 2 & 2 & 2 & 2 & 2 & 1,90 \\
\hline $\begin{array}{l}\text { Quality of } \\
\text { service communication }\end{array}$ & 1 & 1 & 2 & 2 & 2 & 2 & 2 & 2 & 2 & 2 & 1,80 \\
\hline $\begin{array}{l}\text { Complaint handling } \\
\text { procedures }\end{array}$ & 1 & 1 & 1 & 2 & 3 & 2 & 2 & 2 & 1 & 1 & 1,60 \\
\hline Customer data safety & 2 & 1 & 2 & 2 & 2 & 2 & 2 & 2 & 3 & 2 & 2,00 \\
\hline $\begin{array}{l}\text { Multi- } \\
\text { channel strategy and } \\
\text { accessibility / Market } \\
\text { presence }\end{array}$ & 1 & 0 & 3 & 1 & 2 & 2 & 1 & 1 & 1 & 3 & 1,50 \\
\hline Compliance & 1 & 1 & 1 & 1 & 3 & 2 & 2 & 2 & 1 & 2 & 1,60 \\
\hline $\begin{array}{l}\text { Disadvantaged } \\
\text { customers }\end{array}$ & 1 & 0 & 3 & 1 & 1 & 2 & 1 & 1 & 3 & 3 & 1,60 \\
\hline $\begin{array}{l}\frac{1}{0} \\
\frac{1}{4} \\
\frac{2}{11} \\
\frac{1}{4}\end{array}$ & $\exists$ & $\begin{array}{l}\infty \\
\infty \\
0 \\
0\end{array}$ & $\begin{array}{l}8 \\
\text { i }\end{array}$ & $\hat{n}$ & $\begin{array}{l}\text { ते } \\
\text { ती }\end{array}$ & $\begin{array}{l}\text { â } \\
\text { a }\end{array}$ & $\stackrel{\infty}{=}$ & $\stackrel{\infty}{=}$ & $\stackrel{\infty}{\infty}$ & $\overrightarrow{\text { if }}$ & $\stackrel{0}{2}$ \\
\hline
\end{tabular}

Source: Authors' elaboration

\section{Business partners issues reporting by Polish banks}

When studying the banks' CSR reporting of business partners' issues for the year 2016, it should be noted that both, the quality and the scope of the reporting was rather unsatisfactory (Table 9). Most of the analysed CSR reports omitted procurement policy $(0,1)$, as well as the criteria for selecting suppliers $(0,1)$. The industry's disclosure on ethical and environmental standards and dialogue with business partners is assessed very low (both 1,1). From the reporting organisations' perspective, the average scores were very low, ranging from 0.5 to 1.0 .

When examining the CSR reporting of business partner issues for 2019, it should be noticed that the quality and scope of reporting were much more advanced (Table 10). The weakest elements of nonfinancial disclosure of information are again the procurement policy and the supplier selection criteria (both 1,2). Industry disclosure of ethical and environmental standards $(1,8)$ and dialogue with business partners $(1,4)$ still require more attention. From the point of view of the reporting organizations, the average scores were ranging from 1.0 to 2.5. 
Table 9. Business partners' issues reporting by Polish banks -2016 reporting year (published in 2017)

\begin{tabular}{|c|c|c|c|c|c|c|c|c|c|c|c|}
\hline 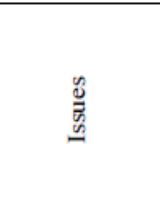 & $\frac{2}{0}$ & $\delta_{\infty}^{\infty}$ & 总 & 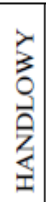 & 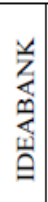 & 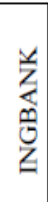 & $\begin{array}{l}\frac{y}{z} \\
\frac{m}{2}\end{array}$ & 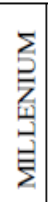 & $\begin{array}{l}0 \\
\frac{y}{4} \\
\substack{a \\
2}\end{array}$ & $\begin{array}{l}\frac{a}{0} \\
0 \\
\frac{1}{2}\end{array}$ & $\frac{\frac{1}{0}}{\frac{\pi}{2}}$ \\
\hline $\begin{array}{l}\text { Procurement } \\
\text { policy }\end{array}$ & 0 & 0 & 0 & 0 & 0 & 0 & 0 & 0 & 1 & 0 & 0,10 \\
\hline $\begin{array}{l}\text { Criteria for } \\
\text { selecting } \\
\text { suppliers }\end{array}$ & 0 & 0 & 0 & 0 & 0 & 0 & 0 & 0 & 1 & 0 & 0,10 \\
\hline $\begin{array}{l}\text { Ethical and } \\
\text { Environmental } \\
\text { Standards }\end{array}$ & 1 & 2 & 1 & 1 & 1 & 1 & 1 & 1 & 1 & 1 & 1,10 \\
\hline $\begin{array}{l}\text { Dialogue with } \\
\text { Business } \\
\text { Partners }\end{array}$ & 1 & 1 & 2 & 1 & 1 & 1 & 1 & 1 & 1 & 1 & 1,10 \\
\hline $\begin{array}{l}\frac{1}{0} \\
\frac{1}{2} \\
\frac{2}{9} \\
\frac{1}{4}\end{array}$ & $\stackrel{8}{6}$ & $\stackrel{n}{\circ}$ & $\stackrel{n}{2}$ & $\stackrel{8}{s}$ & $\stackrel{8}{6}$ & $\stackrel{8}{s}$ & $\stackrel{8}{6}$ & $\stackrel{8}{6}$ & $\stackrel{\mathscr{G}}{-}$ & s. & $\stackrel{8}{\circ}$ \\
\hline
\end{tabular}

Source: Authors' elaboration

Table 10. Business partners' issues reporting by Polish banks - 2019 reporting year (published in 2020)

\begin{tabular}{|c|c|c|c|c|c|c|c|c|c|c|c|}
\hline $\begin{array}{l}\stackrel{g}{g} \\
\underline{n} \\
\underline{n}\end{array}$ & $\frac{\frac{2}{0}}{2}$ & of & 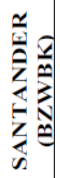 & $=3$ & 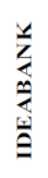 & $\begin{array}{l}\frac{y}{z} \\
\frac{0}{0} \\
\underline{u} \\
\underline{z}\end{array}$ & $\begin{array}{l}\frac{y}{Z} \\
\frac{\hat{z}}{\mathrm{z}}\end{array}$ & 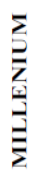 & $\frac{8}{2}$ & $\begin{array}{l}\hat{\bar{c}} \\
0 \\
\frac{1}{2}\end{array}$ & $\begin{array}{l}\frac{1}{2} \\
\frac{2}{x} \\
\frac{x}{x} \\
\frac{1}{2}\end{array}$ \\
\hline $\begin{array}{l}\text { Procurement } \\
\text { policy }\end{array}$ & 1 & 1 & 1 & 1 & 1 & 1 & 1 & 3 & 1 & 1 & 1,20 \\
\hline $\begin{array}{l}\text { Criteria for } \\
\text { selecting } \\
\text { suppliers }\end{array}$ & 1 & 1 & 1 & 1 & 1 & 1 & 1 & 3 & 1 & 1 & 1,20 \\
\hline $\begin{array}{l}\text { Ethical and } \\
\text { Environmental } \\
\text { Standards }\end{array}$ & 1 & 1 & 2 & 2 & 2 & 2 & 2 & 2 & 2 & 2 & 1,80 \\
\hline $\begin{array}{l}\text { Dialogue with } \\
\text { Business } \\
\text { Partners }\end{array}$ & 1 & 1 & 2 & 1 & 1 & 2 & 2 & 2 & 1 & 1 & 1,40 \\
\hline $\begin{array}{l}\frac{1}{0} \\
\frac{\alpha}{2} \\
\frac{\alpha}{2} \\
\frac{2}{2}\end{array}$ & $\stackrel{\Xi}{.}$ & $\stackrel{8}{:}$ & $\stackrel{n_{0}}{2}$ & $\stackrel{\text { If }}{=}$ & $\stackrel{\text { If }}{-}$ & $\stackrel{\text { : }}{=}$ & 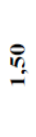 & in & $\stackrel{1}{2}$ & $\stackrel{170}{=}$ & $\stackrel{P}{=}$ \\
\hline
\end{tabular}

Source: Authors' elaboration

\section{Communities' issues reporting by Polish banks}

When analysing banks' CSR reporting for 2016 on community issues, it should be stated that once again the quality of reporting was rather low, and the scope very narrow (Table 11). Industry support for culture or sport is marginal ( 0.9 and 0.8 , respectively), as is commitment to science development (0.6) and support for local business (0.6). Banks' engagement in education (1.0) and social activity (1.5) is slightly better. Organization-level report analysis revealed that average scores were rather low, ranging from 0.33 to 1.67 .

Table 11. Communities' issues reporting by Polish banks - 2016 reporting year (published in 2017)

\begin{tabular}{|c|c|c|c|c|c|c|c|c|c|c|c|}
\hline $\begin{array}{l}\hat{n} \\
\stackrel{n}{n} \\
\underline{n}\end{array}$ & $\frac{\stackrel{\alpha}{0}}{2}$ & $\overbrace{0}^{\infty}$ & $\frac{1}{N}$ & 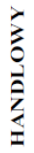 & $\begin{array}{l}\frac{y}{2} \\
\frac{\pi}{3} \\
\frac{\pi}{3}\end{array}$ & $\begin{array}{l}\underline{z} \\
\underline{z} \\
\underline{z} \\
\underline{z}\end{array}$ & $\begin{array}{l}\frac{1}{z} \\
\frac{0}{2}\end{array}$ & 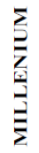 & $\begin{array}{l}0 \\
\frac{1}{2} \\
2\end{array}$ & $\begin{array}{l}\frac{a}{0} \\
\frac{1}{0}\end{array}$ & $\frac{5}{\frac{1}{2}}$ \\
\hline $\begin{array}{l}\text { Promotion/Sponsorship } \\
\text { of culture }\end{array}$ & 1 & 0 & 2 & 2 & 1 & 1 & 0 & 0 & 1 & 1 & 0,90 \\
\hline $\begin{array}{l}\text { Promotion/sponsorship } \\
\text { of sport }\end{array}$ & 1 & 0 & 1 & 2 & 1 & 1 & 0 & 0 & 1 & 1 & 0,80 \\
\hline Supporting education & 1 & 1 & 2 & 1 & 2 & 1 & 0 & 0 & 1 & 1 & 1,00 \\
\hline Development of science & 0 & 0 & 1 & 2 & 1 & 1 & 0 & 0 & 0 & 1 & 0,60 \\
\hline $\begin{array}{l}\text { Social activities and } \\
\text { charity }\end{array}$ & 1 & 2 & 2 & 2 & 2 & 1 & 1 & 1 & 1 & 2 & 1,50 \\
\hline Local business support & 0 & 0 & 1 & 1 & 1 & 1 & 1 & 1 & 0 & 1 & 0,70 \\
\hline $\begin{array}{l}\frac{r}{0} \\
\frac{y}{2} \\
\frac{x}{2}\end{array}$ & $\stackrel{6}{6}$ & $\stackrel{i_{1}}{=}$ & $\stackrel{\vec{x}_{2}}{=}$ & $\stackrel{6}{-6}$ & 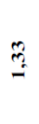 & $\stackrel{\Xi}{=}$ & 3 & $\stackrel{m_{3}}{=}$ & : & $\cong$ & $\hat{\varepsilon}$ \\
\hline
\end{tabular}

Source: Authors' elaboration

Table 12. Communities' issues reporting by Polish banks - 2019 reporting year (published in 2020)

\begin{tabular}{|c|c|c|c|c|c|c|c|c|c|c|c|}
\hline$\stackrel{0}{\mathscr{B}}$ & $\begin{array}{l}\frac{2}{0} \\
\frac{0}{2}\end{array}$ & $\stackrel{n}{\mathscr{m}}$ & 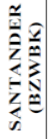 & 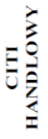 & 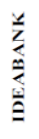 & $\begin{array}{l}\frac{y}{z} \\
\underline{u} \\
\underline{\underline{z}} \\
\underline{z}\end{array}$ & $\begin{array}{l}\frac{y}{z} \\
\hat{z} \\
\underline{z}\end{array}$ & 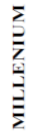 & $\frac{0}{2}$ & $\begin{array}{l}\frac{\vec{m}}{\hat{m}} \\
\frac{\vec{t}}{2}\end{array}$ & $\begin{array}{l}\frac{5}{2} \\
\frac{2}{2} \\
\frac{2}{2}\end{array}$ \\
\hline $\begin{array}{l}\text { Promotion/Sponsorship of } \\
\text { culture }\end{array}$ & 2 & 1 & 2 & 2 & 0 & 2 & 0 & 3 & 2 & 1 & 1,50 \\
\hline $\begin{array}{l}\text { Promotion/sponsorship of } \\
\text { sport }\end{array}$ & 2 & 1 & 3 & 2 & 0 & 2 & 0 & 3 & 1 & 1 & 1,50 \\
\hline Supporting education & 1 & 2 & 2 & 2 & 1 & 2 & 1 & 3 & 2 & 1 & 1,50 \\
\hline Development of science & 0 & 1 & 1 & 2 & 0 & 1 & 0 & 3 & 1 & 1 & 1,00 \\
\hline Social activities and charity & 1 & 2 & 2 & 2 & 1 & 2 & 1 & 2 & 1 & 1 & 1,50 \\
\hline Local business support & 1 & 1 & 1 & 2 & 1 & 2 & 1 & 1 & 1 & 1 & 1,20 \\
\hline $\begin{array}{l}\frac{1}{0} \\
\frac{2}{2} \\
\frac{2}{2} \\
\frac{1}{2}\end{array}$ & $\fallingdotseq$ & $\stackrel{2}{2}$ & $\stackrel{\infty}{-\infty}$ & 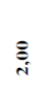 & $\stackrel{0}{s}$ & $\stackrel{0}{=}$ & s. & in & $\stackrel{m}{=}$ & $\stackrel{0}{\Xi}$ & $\stackrel{0}{2}$ \\
\hline
\end{tabular}

Source: Authors' elaboration

When examining banks' reports for 2019, it should be noted that the quality of reporting was much better and the scope was slightly wider (Table 12). The least presented issue was involvement in the development of science (1.0) and support for local business (1.2). The remaining issues were rated 1.5. From the perspective of the reporting organizations, it was revealed that the average scores were moderate, ranging from 0.50 to 2.50 .

\section{Environment issues reporting by Polish banks}

Taking into account the CSR reports for 2016 of the studied banks in terms of environmental issues, it should be emphasized that both the scope and quality 
were rated low again (Table 13). The worst reported were pro-environmental products (0.8), environmental education campaigns (0.8) and environmental sustainability (0.98). The most frequently reported problem was the introduction of environmentally friendly solutions $(1,2)$. From the perspective of the reporting organizations, it can be seen that the average scores were relatively low, ranging from 0.4 to 2.0 .

Table 13. Environment issues reporting by Polish banks - 2019 reporting year (published in 2020)

\begin{tabular}{|c|c|c|c|c|c|c|c|c|c|c|c|}
\hline 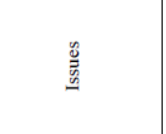 & $\frac{\circ}{2}$ & 号 & 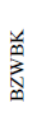 & 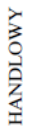 & 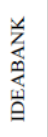 & 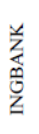 & $\begin{array}{l}\text { 兰 } \\
\frac{m}{\Sigma}\end{array}$ & 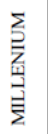 & 妥 & $\begin{array}{l}\overrightarrow{0} \\
0 \\
\frac{\hat{m}}{2}\end{array}$ & 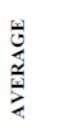 \\
\hline $\begin{array}{l}\text { Environmental } \\
\text { sustainability }\end{array}$ & 0,6 & 2 & 0,8 & 0,8 & 1 & 0,8 & 1 & 1,2 & 1 & 0,6 & 0,98 \\
\hline -water & 1 & 2 & 1 & 1 & 1 & 1 & 1 & 2 & 1 & 1 & 1,20 \\
\hline -energy and fuel & 1 & 2 & 1 & 1 & 1 & 1 & 1 & 1 & 2 & 1 & 1,20 \\
\hline -carbon & 0 & 2 & 0 & 0 & 0 & 0 & 0 & 0 & 0 & 0 & 0,20 \\
\hline -paper & 1 & 2 & 1 & 1 & 2 & 1 & 2 & 2 & 1 & 1 & 1,40 \\
\hline $\begin{array}{l}\text {-waste } \\
\text { management/ } \\
\text { recycling }\end{array}$ & 0 & 2 & 1 & 1 & 1 & 1 & 1 & 1 & 1 & 0 & 0,90 \\
\hline $\begin{array}{l}\text { Introducing } \\
\text { environmentally - } \\
\text { friendly solutions }\end{array}$ & 1 & 2 & 1 & 1 & 2 & 1 & 1 & 1 & 1 & 1 & 1,20 \\
\hline $\begin{array}{l}\text { Pro-environmental } \\
\text { products }\end{array}$ & 0 & 2 & 1 & 0 & 1 & 1 & 1 & 1 & 1 & 0 & 0,80 \\
\hline $\begin{array}{l}\text { Evvironmental } \\
\text { education } \\
\text { campaigns }\end{array}$ & 0 & 2 & 1 & 1 & 1 & 1 & 0 & 1 & 1 & 0 & 0,80 \\
\hline 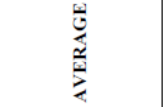 & $\stackrel{9}{\stackrel{9}{0}}$ & $\underset{\mathrm{i}}{\mathrm{i}}$ & 今. & $\stackrel{?}{:}$ & 'ุ̊ & $\stackrel{n}{\circ}$ & : & $\stackrel{g}{=}$ & $\stackrel{\Xi}{=}$ & $\stackrel{9}{+}$ & $\stackrel{\circ}{\circ}$ \\
\hline
\end{tabular}

Source: Authors' elaboration

Table 14. Environment issues reporting by Polish banks - 2019 reporting year (published in 2020)

\begin{tabular}{|c|c|c|c|c|c|c|c|c|c|c|c|}
\hline 萻 & $\frac{2}{0}$ & $\begin{array}{l}0 \\
\mathscr{m}\end{array}$ & 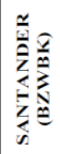 & 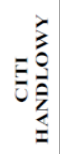 & $\begin{array}{l}\frac{y}{z} \\
\frac{y}{2} \\
\frac{y}{2} \\
\stackrel{y}{=}\end{array}$ & 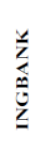 & $\begin{array}{l}\frac{y}{z} \\
\underline{y} \\
\frac{\hat{z}}{z}\end{array}$ & $\begin{array}{l}\bar{z} \\
\bar{z} \\
\bar{z} \\
\vdots \\
⿱ 亠 䒑 \\
\bar{z}\end{array}$ & $\begin{array}{l}0 \\
\frac{1}{4} \\
\frac{1}{2}\end{array}$ & 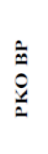 & 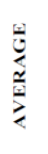 \\
\hline $\begin{array}{l}\text { Environmental } \\
\text { sustainability }\end{array}$ & 1,6 & 1,6 & 1,8 & 2 & 1,2 & 2,6 & 1 & 3 & 3 & 3 & 2,08 \\
\hline -water & 2 & 2 & 1 & 2 & 1 & 3 & 1 & 3 & 3 & 3 & 2,10 \\
\hline -energy and fuel & 2 & 2 & 3 & 2 & 1 & 3 & 1 & 3 & 3 & 3 & 2,10 \\
\hline -carbon & 0 & 0 & 1 & 2 & 0 & 3 & 1 & 3 & 3 & 3 & 1,60 \\
\hline -paper & 2 & 2 & 3 & 2 & 3 & 2 & 2 & 3 & 3 & 3 & 2,50 \\
\hline $\begin{array}{l}\text {-waste } \\
\text { management/recycling }\end{array}$ & 2 & 2 & 1 & 2 & 1 & 2 & 1 & 3 & 3 & 3 & 2,00 \\
\hline $\begin{array}{l}\text { Introducing } \\
\text { environmentally-friendly } \\
\text { solutions }\end{array}$ & 1 & 3 & 2 & 2 & 1 & 2 & 1 & 3 & 1 & 1 & 1,50 \\
\hline $\begin{array}{l}\text { Pro-environmental } \\
\text { products }\end{array}$ & 1 & 3 & 2 & 2 & 1 & 2 & 1 & 3 & 1 & 1 & 1,70 \\
\hline $\begin{array}{l}\text { Environmental education } \\
\text { campaigns }\end{array}$ & 1 & 3 & 2 & 2 & 1 & 2 & 0 & 3 & 1 & 1 & 1,60 \\
\hline $\begin{array}{l}\frac{1}{0} \\
\frac{0}{2} \\
\frac{\alpha}{2} \\
\frac{2}{2}\end{array}$ & $\stackrel{6}{=}$ & $\begin{array}{ll}n \\
3 \\
i\end{array}$ & $\stackrel{0}{:}$ & $\stackrel{8}{i}$ & $\stackrel{\text { ge }}{=}$ & $\frac{n}{i}$ & $\bar{Z}$ & $\stackrel{\Xi}{\circ}$ & $\stackrel{0}{=10}$ & $\stackrel{0}{1}$ & $\stackrel{\mathscr{D}}{-}$ \\
\hline
\end{tabular}

Source: Authors' elaboration
Taking into account the banks' CSR reporting for 2019 on environmental issues, it should be emphasized that both the scope and the quality improved significantly (Table 14). The least disclosed issue was the introduction of environmentally friendly solutions (1.5). while the best-reported issue was environmental sustainability (2.08), with paper reporting being particularly highly rated. From the point of view of the reporting organizations, the average results varied greatly, ranging from 1.05 to 3.0 .

\section{Discussion}

The research carried out shows that the banking sector has coped very well with the implementation of the Directive and has significantly improved both the quality and scope of disclosed non-financial information.

Table 15. CSR issues reporting by Polish banks 2016 reporting year (published in 2017)

\begin{tabular}{|c|c|c|c|c|c|c|c|c|c|c|c|}
\hline$\frac{n}{0}$ & $\frac{\text { of }}{\frac{1}{z}}$ & 象 & 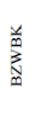 & 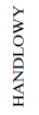 & 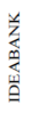 & 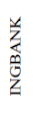 & $\begin{array}{l}\frac{v}{z} \\
\frac{m}{2} \\
\sum\end{array}$ & 竞 & 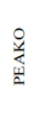 & $\begin{array}{l}\text { 앙 } \\
\frac{8}{2}\end{array}$ & 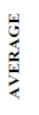 \\
\hline EMPLOYEES & 0,67 & 1,00 & 2,00 & 1,33 & 1,56 & 1,11 & 1,11 & 1,00 & 0,78 & 0,67 & 1,12 \\
\hline $\begin{array}{l}\text { INVESTORS AND } \\
\text { SHAREHOLDERS }\end{array}$ & 0,50 & 0,75 & 1,00 & 1,00 & 1,00 & 1,25 & 1,75 & 0,5 & 0,75 & 0,25 & 0,88 \\
\hline CUSTOMERS & 0,67 & 1,00 & 1,67 & 1,00 & 1,00 & 1,00 & 1,11 & 0,78 & 0,78 & 0,56 & 0,96 \\
\hline BUSINESS PARTNERS & 0,50 & 0,75 & 0,75 & 0,50 & 0,50 & 0,50 & 0,50 & 0,50 & 1,00 & 0,50 & 0,60 \\
\hline COMMUNITIES & 0,67 & 0,50 & 1,50 & 1,67 & 1,33 & 1,00 & 0,33 & 0,33 & 0,67 & 1,17 & 0,92 \\
\hline ENVIRONMENT & 0,40 & 2,00 & 0,95 & 0,70 & 1,25 & 0,95 & 0,75 & 1,05 & 1,00 & 0,40 & 0,95 \\
\hline AVERAGE & 0,54 & 1,00 & 1,30 & 1,03 & 1,07 & 0,97 & 0,92 & 0,66 & 0,83 & 0,59 & 0,89 \\
\hline
\end{tabular}

Source: Author's elaboration

In terms of the banks reporting for the year 2016 (Table 15), it should be noticed that only the employee category was granted an average score over 1.0. The rest of the categories were granted average scores below 1.0. The weakest category of the banking industry's reporting was that of business partners $(0,6)$.

Appraising the banks' reporting for the year 2019 (Table 16), it should be noticed that all six categories were granted an average score much over 1.0. Again, the weakest category of the banking industry's reporting was that of business partners $(1,4)$ together with communities $(1,36)$. 
Table 16. CSR issues reporting by Polish banks 2019 reporting year (published in 2020)

\begin{tabular}{|c|c|c|c|c|c|c|c|c|c|c|c|}
\hline 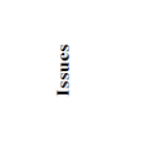 & $\frac{\frac{2}{0}}{\frac{\varrho}{2}}$ & $\stackrel{f}{\Leftrightarrow}$ & 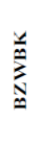 & 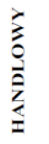 & 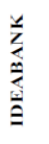 & $\begin{array}{l}\frac{1}{z} \\
\underline{u} \\
\underline{u} \\
\underline{z}\end{array}$ & $\begin{array}{l}\frac{y}{z} \\
\hat{y}\end{array}$ & 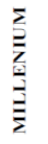 & $\begin{array}{l}\stackrel{a}{2} \\
\frac{1}{2}\end{array}$ & $\begin{array}{l}\hat{\bar{m}} \\
\hat{\theta} \\
\frac{\hat{x}}{2}\end{array}$ & $\begin{array}{l}\frac{1}{0} \\
\frac{\alpha}{2} \\
\frac{2}{2}\end{array}$ \\
\hline EMPLOYEES & 2,11 & 1,89 & 2,66 & 2,00 & 1,56 & 2,56 & 2,22 & 2,89 & 2,44 & 2,0 & 2,22 \\
\hline $\begin{array}{l}\text { INVESTORS AND } \\
\text { SHAREHOLLDERS }\end{array}$ & 1,25 & 1,25 & 2,75 & 1,50 & 1,50 & 2,00 & 2.00 & 2,00 & 1,75 & 1,50 & 1,75 \\
\hline CUSTOMERS & 1,11 & 0,89 & 2,00 & 1,33 & 2,22 & 2,22 & 1,78 & 1,78 & 1,89 & 2,11 & 1,76 \\
\hline $\begin{array}{c}\text { BUSINESS } \\
\text { PARTNERS }\end{array}$ & 1,00 & 1,00 & 1,50 & 1,25 & 1,25 & 1,50 & 1,50 & 2,50 & 1,25 & 1,25 & 1,40 \\
\hline CONMUNITIES & 1,17 & 1,33 & 1,83 & 2,00 & 0,50 & 1,83 & 0,50 & 2,50 & 1,33 & 1,00 & 1,36 \\
\hline ENVIRONMENT & 1,15 & 2,65 & 1,95 & 2.00 & 1,05 & 2,15 & 1,11 & 3.00 & 1,50 & 1,50 & 1,80 \\
\hline AVERAGE & 1,30 & 1,50 & 2,11 & 1,68 & 1,35 & 2,04 & 1,52 & 2,45 & 1,69 & 1,56 & 1,72 \\
\hline
\end{tabular}

Source: Author's elaboration

The analysed reports show that the quality of reporting in the case of the six analysed categories was quite similar, but the scope of reporting was very diverse. The broadest range covers the categories of employees and the environment, while the narrowest covers business partners, investors and shareholders. However, the analysed reports of the banks were very diverse and one could find very good and very weak reports.

The results of the conducted analyses also indicate the strongest and weakest elements disclosed in the non-financial reports of Polish banks. The best ones are employee issues and environmental sustainability issues. They can be a good example for the entire banking sector, not only in terms of the reporting method itself, but also the solutions used in the scope of individual issues. The remaining elements, although much better presented after than before the Directive implementation, still require a lot of work on the part of the entire sector. However, in each of the researched issues, there are very good practices that should be promoted within the banking and entire financial sector.

The conducted analyses are not only a diagnosis of a qualitative change in the scope of CSR reporting in accordance with the guidelines of the Directive, but are a starting point for comparisons with other EU countries covered by the Directive, as well as other regions more or less advanced in non-financial reporting. It is important to take into account the specificity of the financial sector in these comparisons, including the specificity of the banking sector, which, due to its economic and social role, should take actions consistent with its activities (e.g. in the field of education, financial education of the society is particularly important, and in terms of impact on the natural environment, it is important to reduce the consumption of paper and introduce new products and services that will have a neutral or positive impact on the condition of the natural environment). It is worth taking advantage of good international practices, but also sharing with the international community solutions that the sector deems particularly worth promoting.

\section{Conclusions}

The study presented in the article focused on the scope and quality of CSR reporting of the Polish banking sector in the six categories: employees, investors and shareholders, customers, business partners, communities and the environment. The results of the study show that the banking sector has dealt very well with the implementation of the Directive and has made significant progress in terms of both the scope and the quality of non-financial information disclosure.

Nevertheless, due to the role of the banking sector in the economy and society's expectations regarding the social responsibility of banks, further intensive work on CSR reporting in the banking sector is necessary. The diagnostic tools proposed by the researchers (e.g., the one used in this study) and practitioners of non-financial reporting, as well as organizations that develop standards, frameworks and guidance, and good national and international practices in areas that need changes, can support this process.

Although the conducted analyses allow for a holistic view of the non-financial reporting of the Polish banking sector, it should be emphasized that this assessment has some limitations, as the sample covers only the largest banks. Moreover, the study concerned only the Polish banking sector and it is possible that the analysis of banks' reports from other EU countries could have produced different results. Thirdly, because we only study 2 selected years, this analysis has not reveal the dynamics of changes in the scope and quality of reporting in the long term. Analysing trends over several reporting years could reveal different patterns in CSR reporting practices due to the dynamics of the business environment or the bank's CSR maturity.

Despite these limitations, the authors believe that the study makes an important contribution to existing literature. According to the authors' knowledge, the research results are the first to present an in-depth analysis of the impact of the NFI Directive on the CSR reports of financial institutions and their reviews. The characteristics of banking sector 
practices presented in this paper can help other financial institutions with CSR reporting and encourage them to adhere to recognized standards. From a theoretical perspective, the article adds to current knowledge and provides an overview of banking sector reporting practices, showing strengths and weaknesses in this area. The research results show that the banking sector reporting practices, although significantly improved, are still at an early stage.

In future research, it would be interesting to find out what is the scope and quality of CSR reporting in the banking sector in relation to other "old" and "new" EU member states. It would also be very valuable to see if the NFI Directive has had an impact on the quality and scope of corporate social responsibility reporting in other industries. From the perspective of the banking sector, it would be very useful to research particular issues in Poland and abroad in order to identify trends and good practices consistent with the financial sector.

\section{References:}

[1] Directive 2014/95/EU (NFRD) of the European Parliament and of the Council of 22 October 2014 Amending Directive 2013/34/EU as Regards Disclosure of Non-Financial and Diversity Information by Certain Large Undertakings and Groups; EU law: Brussels, Belgium.

[2] San-Jose, L., Retolaza, J. and J. Gutiérrez, Are Ethical Banks Different? A Comparative Analysis Using the Radical Affinity Index", Journal of Business Ethics, 100, 2011, pp. 151173.

[3] Bauer K., Regulatory Conditions of Cooperative Banks' Financial Reporting in Poland, Współczesne uwarunkowania sprawozdawczości i rewizji finansowej, Fundacja Uniwersytetu Ekonomicznego, Kraków, 2015, pp. 13-23.

[4] Bauer K., Centorrino G., Financial Statements of Banks as a Source of Information About Implementation of IFRS 15: The Evidence from Poland, Journal of Modern Accounting and Auditing, 13(6), 2017, pp. 235-248.

[5] Broz Tominac S., Bauer K. 2017, Regulations for the Preparation of Financial Statements by Banks in Croatia and Poland, Argumenta Oeconomica Cracoviensia, 16, 2017, pp. 81-97.

[6] Lentner, C., Szegedi, K. and T. Tatay, Corporate social responsibility in the banking sector, Public Finance Quarterly, 1, 2015, pp. 95-103.

[7] Wiseman, J., An evaluation of environmental disclosures made in corporate annual reports,
Accounting, Organizations and Society, 7(1), 1982, pp. 53-63

[8] OCR, 2015, Corporate social responsibility, Oxford Cambridge and RSA. Retrieved from www.ocr.org.uk/Images/169741-topicexploration-corporate-social-responsibilityteacherpack-.pdf (Accessed 12 July 2020)

[9] Bowen, H. R., Social responsibilities of the businessman", New York: Harper \& Brothers, 1953.

[10] Carroll, A.B., A three-dimensional conceptual model of corporate social performance", Academy of Management Review, 4, 1979.

[11] Frederick, W. C., The Moral Authority of Transnational Corporate Codes", Journal of Business Ethics, 10, 1991, pp. 165-177

[12] Strand, R., A systems paradigm of organizational adaptations to the social environment", Academy of Management Review, 8, 1983, pp. 90-96.

[13] Stanwick, P., A. and S., D. Stanwick, The relationship between corporate social performance and organizational size, financial performance and environmental performance: an empirical examination, Journal of Business Ethics, 17, 1998, pp. 195-204.

[14] Swanson, D., Addressing a theoretical problem by reorienting the corporate social performance model, Academy of Management Review, 20(1), 1995, pp. 43-64.

[15] Wood, D., Corporate social performance revisited, Academy of Management Review, 16(4), 1991, pp. 691-718.

[16] McWilliams, A., Siegel, D. and P., M. Wright, Corporate Social Responsibility: Strategic Implications, Journal of Management Studies, 43 (1), 2006, pp. 1-18.

[17] Kolk, A., Trajectories of sustainability reporting by MNCs, Journal of World Business, 45(4), 2010, pp. 367-374.

[18] Owen, D. L., Swift, T., and K. Hunt, Questioning the Role of Stakeholder Engagement in Social and Ethical Accounting, Auditing and Reporting, Accounting Forum, 25(3), 2001, pp. 264-282.

[19] Burritt, R. L., and S. Schaltegger, Sustainability accounting and reporting: Fad or trend?, Accounting, Auditing \& Accountability Journal 23 (7), 2010, pp. 829-846.

[20] KPMG, The road ahead: The KPMG Survey of Corporate Responsibility Reporting 2017, https://assets.kpmg.com/content/dam/kpmg/be/ pdf $/ 2017 / \mathrm{kpmg}$-survey-of-corporateresponsibility-reporting-2017.pdf (Accessed 12 July 2020) 
[21] INTOSAI Working Group on Environmental Auditing (WGEA), June 2013, "Sustainability Reporting: Concepts, Frameworks and the Role of Supreme Audit Institutions", http://www.environmentalauditing.org (Accessed 12 July 2020)

[22] Eccles R., G, and D. Saltzman, Achieving Sustainability through Integrated Reporting. Stanford Social Innovation Review, Leland Stanford Jr. University, 2011.

[23] PWC, 2011, May, Tomorrow's Corporate Reporting - A critical system at risk http://www.pwc.com/gx/en/corporatereporting/integratedreporting/publications/tomo rrows-corporate-reporting-a-critical-system-atrisk.jhtml (Accessed 12 July 2020)

[24] CFA Institute, 2017, Global Perceptions of Environmental, Social and Governance (ESG) Investing, CFA Institute, https://www.cfainstitute.org/en/research/survey -reports/esg-survey-2017 (Accessed 12 July 2020)

[25] PRI, Principles for investors in inclusive Finance. $\quad$ http://www.unpri.org/files/2012. 05.02\%20 PiiF.pdf (Accessed 10 July 2020)

[26] EY Tomorrow's Investment Rules 2.0, EY, London 2016

[27] Cerasi V., Oliviero T., 2015 CEO compensation, regulation, and risk in banks: Theory and evidence from the financial crisis. International Journal of Central Banking,11(3) 2015, pp. 241-297.

[28] CFERF, 2009, Corporate Sustainability Reporting in Canada. Retrieved January 1, 2014, from Canadian Financial Executives Research Foundation:http://www.feicanada.org/files/CS \%20Reporting\%20(SINGLE)\%20FINAL\%20 Web\%20V ersion\%20MAR\%2011-09.pdf (Accessed 2 July 2020)

[29] Scholtens, B., Corporate Social Responsibility in the International Banking Industry, Journal of Business Ethics, 86, 2009, pp. 159-175

[30] Viganò, F. and D. Nicolai, CSR in the European Banking sector: evidence from a survey. In: Barth, R. and F. Wolff, (ed.), Corporate social Responsibility in Europe: Rhetoric and Realities, Edward Elgar Publishing Inc., 2009

[31] Van Wensen, K., Broer, W., Klein, J. and J. Knopf, The State of Play in Sustainability Reporting in the European Union, European Commission, Brussels, 2011 http://ec. europa.eu/social/BlobServlet?docId6727\&langI den (Accessed 7 June 2020).

[32] https://www.ebf.eu/poland/ (Accessed 20 December 2020).
[33] Matuszak, Ł., and Różańska, E., An examination of the relationship between CSR disclosure and financial performance: The case of polish banks. Accounting and Management Information Systems, 16(4), 2017, 522-533. doi:http://dx.doi.org/10.24818/jamis.2017.0400 5

[34] Tunowski, R., Sustainability of Commercial Banks Supported by Business Intelligence System." Sustainability 12(11), 2020, 4754. doi:http://dx.doi.org/10.3390/su12114754.

[35] Matuszak, Ł. and Różańska, E., CSR Disclosure in Polish-Listed Companies in the Light of Directive 2014/95/EU Requirements: Empirical Evidence." Sustainability 9(12), 2017, 2304. doi:http://dx.doi.org/10.3390/su9122304.

[36] Zabawa, J., and Kozyra, C., Eco-Banking in Relation to Financial Performance of the Sector-The Evidence from Poland. Sustainability 2020, doi:http://dx.doi.org/10.3390/su12062162.

[37] Krasodomska J., CSR disclosures in the banking industry. Empirical evidence from Poland", Social Responsibility Journal, 11(3), 2015, pp. 406-423

[38] Adams, C. A., Hill W. Y. and C. B. Roberts, Corporate Social Reporting Practices in Western Europe: Legitimating corporate behaviors", Journal of British Accounting Review, 30(1), 1998, pp. 1-21

[39] Rupley, K. H., Brown, D. and M. Scott, 2017 "Evolution of Corporate Reporting: From Stand-Alone Corporate Social Responsibility Reporting to Integrated Reporting”, Research in Accounting Regulations, Kelley School of Business Research 17-73, https://ssrn.com/abstract=3062403 (Accessed 12 July 2020)

[40] Unerman, J., Methodological Issues: Reflections on Quantification in Corporate Social Reporting Content Analysis", Accounting, Auditing \& Accountability Journal, 13(5), 2000, pp. 667-680

[41] Vourvachis, P. and T., Woodward, Content analysis in social and environmental reporting research: trends and challenges", Journal of Applied Accounting Research, 16(2), 2015, pp. $166-195$

[42] Milne, M.J. and R. W. Adler, 1999, "Exploring the Reliability of Social and Environmental Disclosures Content Analysis", Accounting, Auditing and Accountability Journal, 12(2), 1999, pp. 237-256

[43] Grbich, C., Qualitative Data Analysis: An Introduction, Thousand Oaks, Calif: Sage, 2007. 
[44] Powers, B. and T. Knapp, Dictionary of Nursing Theory and Research (3rd edn). New York: Springer Publishing Company, 2006

[45] Krippendorff, K., Content Analysis: An Introduction to its Methodology, 3rd Ed., Sage, Thousand Oaks, 2013, CA.

[46] Vaismoradi, M., Salsali, M. and P. Mark, Patient safety: nursing students' perspectives and the role of nursing education to provide safe care, Int. Nurs. Rev. 58, 2011, pp. 434-442.

[47] Mayring P., Qualitative Content Analysis. Forum: Qualitative Social Research, www.qualitative-research.net/index.php/ fqs/article/view/1089/2385 (Accessed 12 July 2020)

[48] Elo S. and H. Kyngäs, The qualitative content analysis process, J. Adv. Nurs. 62, 2008, pp. 107-115.

[49] Gray, R., Kouhy, R. and S. Lavers, Corporate social and environmental reporting: a review of the literature and a longitudinal study of UK disclosure, Accounting, Auditing and Accountability Journal, 8 (2), 1995, pp. 47-77.

[50] Beattie, V., McInnes, B. and S. Feanley, A methodology for analysing and evaluating narratives in annual reports: a comprehensive descriptive profile and metrics for disclosure quality attributes, Accounting Forum, 28, 2004, pp. 205-236.

[51] Cormier, D., Magnan, M., and B.V. Velthoven, Corporate Environmental Disclosure Qualities in Large German Companies: Economic Incentives, Public Pressures or Institutional Conditions?, European Accounting Review 14(1), 2005, pp.3-39.

[52] Ten, E.E., Can Stakeholder Theory Add to Our Understanding of Malaysian Environmental Reporting Attitudes?, Malaysian Accounting Review 8(2), 2009, pp.85-110.

[53] Bewley, K. and Y. Li, Disclosure of environmental information by Canadian manufacturing companies: a voluntary disclosure perspective, Advances in Environmental Accounting and Management 1, 2000, pp. 201-226.

[54] Hughes, S.B., Anderson, A., and S. Golden, Corporate environmental disclosures: are they useful in determining environmental performance?, Journal of Accounting and Public Policy, 20(3), 2001, pp. 217-240.

[55] Patten, D.M., The relation between environmental performance and environmental disclosure: a research note, Accounting, Organizations and Society, 27(8), 2002, pp.763773.

[56] Walden, W.D. and B.N. Schwartz, Environmental disclosures and public policy pressure, Journal of Accounting and Public Policy, 16(2),1997, pp.125-154.

[57] Galani, D., Alexandridis, A., and A. Stavropoulos, The Association between the Firm Characteristics and Corporate Mandatory Disclosure the Case of Greece, World Academy of Science, Engineering and Technology, 77, 2011, pp. 101-107.

[58] Eljayash, K M., Documentation of Environmental Disclosure Practices in the Oil Companies in the Countries of the Arab Spring - Some Evidences from Egypt, Libya and Tunisia, Journal of Economics, Business and Management, 3(10), 2015, pp. 954-960.

Contribution of individual authors to the creation of a scientific article (ghostwriting policy)

Authors equally contributed to the paper.

\section{Sources of funding for research presented in a scientific article or scientific article itself}

This research received no external funding

\section{Creative Commons Attribution License 4.0 (Attribution 4.0 International, CC BY 4.0)}

This article is published under the terms of the Creative Commons Attribution License 4.0

https://creativecommons.org/licenses/by/4.0/deed.en_US 